\title{
Self-efficacy guru kelas dalam membimbing siswa slow learner
}

\author{
Farida Agustin Riyanda Putri, Fuadah Fakhruddiana \\ Fakultas Psikologi, Universitas Ahmad Dahlan. Jl Kapas 9, Semaki, Umbulharjo, Yogyakarta, 55166, \\ Indonesia \\ * Corresponding Author. E-mail: faridaagustinrp@gmail.com
}

\begin{abstract}
Abstrak: Tujuan dari penelitian ini adalah untuk mengetahui dinamika dan faktor-faktor self-efficacy guru kelas dalam membimbing siswa slow learner. Metode penelitian yang digunakan dalam penelitian ini adalah metode penelitian kualitatif dengan pendekatan studi kasus. Metode pengambilan data dilakukan dengan metode wawancara. Pendekatan analisis yang digunakan dalam penelitian ini adalah analisis isi (content analysis) serta menggunakan triangulasi sumber dalam uji kredibilitas penelitian. Berdasarkan hasil penelitian, Subjek I memiliki keyakinan dalam membimbing siswa slow learner. Subjek I memiliki banyak ide dan inovasi dalam mengatasi kelambanan siswa slow learner. Sedangkan faktor yang mempengaruhi self-efficacy Subjek I adalah pengalaman keberhasilan terdahulu, pengalaman orang lain, persuasi verbal, kondisi fisik dan afeksi, serta faktor berupa kondisi lingkungan sekitar. Untuk Subjek II, ditemukan bahwa subjek memiliki rasa pesimis dalam menghadapi siswa slow learner. Subjek II merasa kesulitan ketika menghadapi siswa slow learner, sehingga tidak banyak cara yang dilakukannya dalam menghadapi siswa slow learner. Faktor yang mempengaruhi selfefficacy Subjek II hampir sama dengan Subjek I yakni self-efficacy subjek dipengaruhi oleh pengalaman keberhasilan terdahulu, pengalaman orang lain, persuasi verbal dan kondisi fisik dan afeksi. Temuan dari penelitian ini adalah atmosfer sekolah yang ternyata memberikan spirit yang berbeda bagi kedua subjek.
\end{abstract}

Kata Kunci: guru kelas, self-efficacy, slow learner

\section{Self-efficacy of classroom's teacher in guiding slow learner student}

\begin{abstract}
The purpose of this study was to determine the dynamics and factors of classroom teacher's selfefficacy in guiding slow learner students. The method used in this research is qualitative research methods with case study approach. Method of data collection conducted by interview. Analysis approach used in this research is content analysis and using triangulation in research credibility test. Based on the research, the first subject has efficacy in guiding slow learner students. The subject has a lot of ideas and innovations in overcoming inaction slow learner students. While the factors was influence subject was namely enactive mastery experience, vicarious experience, verbal persuasion and physiological and affective states, and factors such as environmental conditions. For the second subject, it was found that the subject has a sense of pessimism in guiding of slow learner students. Subject find difficulties when she guiding slow learner students, so there isn't a lot of ways that subject do in the guiding of slow learner students. Factors that influence self-efficacy of the second subject is influenced by four factors namely enactive mastery experience, vicarious experience, verbal persuasion and physiological and affective states. The conclusion from this study is that there are differences in self-efficacy of teachers in the face of slow learner students. Differences between subject I and subject II lies in the school atmosphere that gives a different spirit to the second subject.
\end{abstract}

Keywords: classroom's teacher, self-efficacy, slow learner

\section{PENDAHULUAN}

Dunia pendidikan di Indonesia berkembang secara dinamis, seiring dengan penemuanpenemuan baru di bidang pendidikan secara lebih luas. Namun, seiring dengan perkembangannya, pendidikan di Indonesia tidak terlepas dari berbagai permasalahan yang mengikutinya. Kualitas seorang guru sangat berperan penting dalam proses belajar mengajar untuk peningkatan kualitas pendidikan di Indonesia.

Sebagai guru yang profesional, seorang guru dituntut untuk memiliki tiga kemampuan. Pertama, kemampuan kognitif, berarti guru harus menguasai materi, metode, media, dan mampu merencanakan dan mengembangkan kegiatan pembelajarannya. Kedua, kemampuan afektif, berarti 


\section{J PK (J urnal Pendidikan Khusus), 14 (1), 2018 - 2}

Farida Agustin Riyanda Putri, Fuadah Fakhruddiana

guru memiliki akhlak yang luhur, terjaga perilakunya sehingga ia akan mampu menjadi model yang bisa diteladani oleh siswanya. Ketiga, kemampuan psikomotorik, berarti guru dituntut memiliki pengetahuan dan kemampuan dalam mengimplementasikan ilmu yang dimiliki dalam kehidupan sehari-hari (Suyanto \& Jihad, 2013).

Dalam model pembelajaran Bandura, faktor person (kognitif) guru sangat berpengaruh terhadap keberhasilan proses belajar mengajar. Faktor person (kognitif) yang ditekankan Bandura pada masa ini adalah self-efficacy, yakni keyakinan bahwa seseorang bisa menguasai situasi dan menghasilkan hasil positif (Santrock, 2010). Self-efficacy guru merupakan kepercayaan yang dimiliki oleh seorang guru terhadap kapasitasnya untuk mempengaruhi performa siswanya. Siswa memerlukan dukungan eksternal ketika proses pembelajaran untuk mencapai hasil akhir pembelajaran yang maksimal. Bandura juga menyatakan bahwa self-efficacy dapat menjembatani antara pengetahuan yang dimiliki dengan perilaku-perilaku tertentu (Santrock, 2010). Artinya self-efficacy berperanan dalam menentukan munculnya perilaku yang diharapkan dalam hal ini perilaku guru dalam meningkatkan prestasi siswanya. Bandura mendefinisikan self-efficacy sebagai keyakinan individu akan kemampuannya untuk mengatur dan melaksanakan hal-hal yang diperlukan untuk melakukan tindakan sehingga menghasilkan pencapaian yang diinginkan (Bandura, 1997, p.3 dalam Skaalvik \& Skaalvik, 2007). Atas dasar hal tersebut, self-efficacy guru dikonseptualisasikan sebagai keyakinan guru secara individual dalam kemampuannya untuk merencanakan, mengatur, dan menjalankan kegiatan yang mengarah pada pencapaian tujuan pendidikan (Skaalvik \& Skaalvik, 2007).

Permasalahan lain yang terdapat pada proses pembelajaran adalah dari siswa atau peserta didik. Salah satu yang menjadi fokus dalam penelitian ini adalah adanya kasus lambat belajar atau slow learner. Slow learner atau anak lambat belajar adalah mereka yang memiliki prestasi belajar rendah (dibawah rata-rata anak pada umumnya) seluruh area akademik, tetapi mereka ini bukan tergolong anak terbelakang mental. Skor tes IQ mereka menunjukkan skor antara 70-90 (menurut Binet dan Wechler antara 70-89). Anak slow learner juga disertai dengan ketidakmampuan/ kekurang-mampuan untuk belajar dan untuk menyesuaikan diri dengan mata pelajaran yang diikuti (Santrock, 2010).

Siswa slow learner cukup dirasakan keberadaannya di dunia pendidikan. Dalam penelitian Pujianingsih pada tahun 2002 di kecamatan Berbah Sleman ditemukan bahwa anak berkesulitan belajar sebesar 36\%, dimana $12 \%$ di antaranya adalah siswa slow learner. Penelitian lain dilakukan oleh Widayanti, Rusmawanti, dan Siswati di SD Negeri Gisikdrono Semarang pada tahun 2012, dengan menyajikan tes inteligensi pada 24 anak, didapatkan 46\% siswa mengalami kesulitan belajar spesifik dan 54\% adalah siswa lambat belajar. Sedangkan hasil penelitian dari Balai Pengembangan Pendidikan Khusus Provinsi Jawa Tengah pada tahun 2014 didapatkan hasil 65\% dari seluruh siswa inklusi, mengalami lambat belajar.

Siswa slow learner atau lambat belajar tentu memerlukan guru yang mampu menerima, menyesuaikan diri dan mengembangkan sesuai dengan kondisi dan kebutuhan anak dalam belajar (Rudiyati, Pujianingsih \& Ambarwati, 2010). Guru yang mampu memahami situasi kelas dan mengatasi problematika dalam kelas menurut Melby merupakan guru yang memiliki self-efficacy yang tinggi (Santrock, 2010). Oleh karena itu, siswa slow learner yang mengalami kesulitan dalam menyerap materi pelajaran lainnya yang disampaikan guru, memerlukan guru yang memiliki selfefficacy yang memadai dalam proses pembelajaran. Schunk dan Meece (2006) dalam Skaalvik \& Skaalvik (2009), self-efficacy mempengaruhi tujuan dan perilaku seseorang dan dipengaruhi oleh tindakan seseorang dan kondisi lingkungannya. Keyakinan diri akan menentukan seberapa besar kesempatan lingkungan dan rintangan akan diterima (Bandura, 2006a) dan mempengaruhi pilihan aktivitas, seberapa besar upaya akan dilakukan dalam aktivitas tersebut, dan seberapa lama seseorang akan tekun menghadapi rintangan (Skaalvik \& Skaalvik, 2009). Apalagi menghadapi anak berkebutuhan khusus dalam hal ini siswa slow-learner tentunya membutuhkan keyakinan dan ketekunan yang memadai.

Self-efficacy guru diartikan sebagai perluasan dari kepercayaan guru akan kapasitasnya dalam mempengaruhi performansi siswa (Bergman, McLaughlin, Bass, Pauly \& Zellman, 1977, p. 137), atau sebagai kepercayaan atau keyakinan guru yang dapat memberi pengaruh terhadap seberapa baik siswa akan belajar, bahkan pada mereka yang mengalami kesulitan atau tidak termotivasi (Guskey \& Passaro, 1994, p. 4 dalam Brouwers \& Tomic, 1999). Hal ini akan memberikan pengaruh bagi siswa dari kedua subjek, yang merupakan siswa dengan potensi kognitif yang cenderung kurang. 


\section{J PK (J urnal Pendidikan Khusus), 14 (1), 2018 - 3}

Farida Agustin Riyanda Putri, Fuadah Fakhruddiana

Penelitian lain pernah dilakukan oleh Hadjam dan Widhiarso (2011) dengan mengaitkan self efficacy mengajar sebagai mediator peranan faktor kepribadian terhadap performansi mengajar guru. Dari penelitian tersebut didapatkan hasil bahwa efikasi mengajar menjadi mediator yang signifikan di dalam peranan dua faktor kepribadian yaitu keuletan dan keterbukaan. Guru yang memiliki self efficacy yang tinggi, cenderung lebih ulet dan terbuka dalam membimbing siswa siswanya di kelas (Hadjam \& Widhiarso, 2011). Mereka lebih mampu mengolah dirinya menjadi figur guru yang mampu mengekspresikan setiap materi yang disampaikan sehingga seluruh siswanya dapat menerimanya dengan baik (Hadjam \& Widhiarso, 2011).

Dalam self efficacy terdapat tiga aspek yang mempengaruhi tingkat keyakinan seorang guru dalam mengajar. Pertama adalah magnitude/level yang merupakan suatu tingkat rasa keyakinan seseorang terhadap tindakan yang dilakukan. Hal ini menunjukkan bahwa sejauh mana seorang guru kelas memiliki keyakinan untuk melakukan tindakan demi mengantarkan siswa-siswanya menjadi siswa yang cerdas dan memiliki prestasi akademis maupun non akademis, termasuk dalam menangani siswa slow learner di dalam kelas.

Aspek yang kedua adalah strength yang mengacu pada besarnya kemantapan seseorang terhadap keyakinan atau harapan yang dibuatnya. Ketika seorang guru memiliki harapan besar untuk mewujudkan siswanya menjadi siswa yang berprestasi, ia harus memiliki kemantapan untuk meraih apa yang menjadi harapannya tersebut. Seorang guru yang memiliki kemantapan, cenderung siap untuk melangkah dan menghadapi segala permasalahan yang akan terjadi, termasuk permasalahan menyangkut siswa-siswanya.

Aspek yang ketiga adalah generality yang berkaitan dengan cakupan bidang atau perilaku. Hal ini kaitannya dengan pengalaman yang sudah pernah guru dapatkan. Seorang guru yang senang mencoba berbagai hal baru, akan memiliki pengalaman yang lebih terutama dalam menghadapi berbagai permasalahan. Individu yang memiliki pengalaman pernah menyelesaikan tugas-tugas sebelumnya akan lebih mudah menghadapi tugas-tugas yang selanjutnya yang hampir sama bahkan lebih luas lagi.

Mengutip dari artikel The council for exceptional children yang disadur oleh Didi Tarsidi dari Universitas Pendidikan Indonesia, bahwa salah satu kegiatan atau sistem pendukung yang menentukan keberhasilan pembelajaran inklusi adalah sikap dan keyakinan guru. Guru reguler harus memiliki keyakinan bahwa siswa berkebutuhan khusus dapat berhasil. Berdasarkan uraian tersebut, penulis tertarik untuk meneliti bagaimana self-efficacy seorang guru dalam menghadapi siswa slow learner.

\section{METODE}

Pendekatan yang digunakan dalam penelitian ini adalah pendekatan kualitatif. Untuk mewujudkan pemahaman mendalam mengenai fenomena apa yang dialami oleh subjek, peneliti menggunakan metode kualitatif dengan pendekatan studi kasus. Pendekatan studi kasus merupakan fenomena khusus yang hadir dalam suatu konteks yang terbatasi (bounded context), meski batas antara fenomena dan konteks tidak sepenuhnya jelas.

Pada penelitian ini, subjek berjumlah dua orang. Subjek dipilih dengan menentukan terlebih dahulu siswa yang mengalami lambat belajar atau slow learner, kemudian guru kelas yang menangani siswa tersebut dipilih untuk dijadikan subjek. Lokasi penelitian dilakukan di dua sekolah dasar di Kabupaten Bantul Yogyakarta yaitu MD AI dan SD N X.

Metode pengambilan data menggunakan wawancara. Wawancara adalah percakapan dan tanya jawab yang diarahkan untuk mencapai tujuan tertentu (Banister dalam Poerwandari, 2009). Observasi diarahkan hanya untuk memperkuat kualitas data yang diperoleh melalui wawancara, dengan memperhatikan ekspresi, gerakan, dan hal-hal lain yang menyertai wawancara terhadap subjek dan significant person.

Setelah menentukan subjek penelitian, kemudian dilakukan pengambilan data dari wawancara dan observasi terhadap subjek. Untuk mendapat data yang lebih akurat, maka dilakukan wawancara terhadap significant person. Data yang diperoleh dari wawancara akan dibuat transkrip yang kemudian akan dianalisis menggunakan analisis isi. Dari hasil analisis data tersebut peneliti merumuskan hasil penelitian dan membuat kesimpulan.

Untuk menguji validitas dan kredibilitas, dalam penelitian ini menggunakan triangulasi sumber, yaitu significant person. Sumber data diperoleh dari 2 orang subjek penelitian dan 2 orang dari significant person yang berbeda. Informasi yang didapat dari subjek dan significant person akan 


\section{J PK (J urnal Pendidikan Khusus), 14 (1), 2018 - 4}

Farida Agustin Riyanda Putri, Fuadah Fakhruddiana

dibandingkan kebenarannya. Berbagai pandangan itu diharapkan dapat melahirkan keluasan pengetahuan untuk memperkaya hasil penelitian.

\section{HASIL DAN PEMBAHASAN}

Self efficacy seorang guru adalah keyakinan guru terhadap keefektifan kemampuannya sendiri dalam membangkitkan gairah dan kegiatan para siswanya (Syah, 2011). Guskey dan Pasaro (Pajares, F \& Tim, 2006) juga menambahkan bahwa self efficacy guru merupakan keyakinan bahwa mereka dapat mempengaruhi seberapa baik siswa belajar, bahkan untuk siswa yang mungkin sulit atau kurang termotivasi.

Siswa slow learner memerlukan pendampingan secara khusus dan mendalam oleh guru yang menanganinya. Lebih lanjut, siswa slow learner memiliki hak untuk bersekolah di sekolah regular atau umum. Hal ini sesuai dengan deklarasi Pemerintah Daerah Istimewa Yogyakarta pada tahun 2012, bahwa DIY sebagai daerah yang mendukung pendidikan inklusi bagi semua anak berkebutuhan khusus usia sekolah sehingga mereka dapat diterima dan belajar berdampingan di kelas regular. Oleh karena itu, keberadaan siswa slow learner harus menjadi perhatian khusus bagi para guru di sekolah sekolah regular atau umum. Guru yang memiliki self efficacy diharapkan mampu membimbing siswa slo slearner dalam menngoptimalkan kemampuan yang mereka miliki.

Dari penelitian yang telah dilakukan, kedua subjek memiliki gambaran self-efficacy yang berbeda ketika menghadapi siswa slow learner. Berikut gambaran self-efficacy dan faktor-faktor yang mempengaruhi kedua subjek dalam menghadapi siswa slow learner:

\section{A. Subjek I}

\section{Dinamika Self-efficacy Guru Kelas dalam Membimbing Siswa Slow Learner}

Secara umum, self-efficacy ditentukan oleh 3 dimensi atau aspek yaitu magnitude/level, strength dan generality (Bandura, 1997).

a. Magnitude/level

Magnitude/level merupakan suatu tingkat rasa keyakinan seseorang terhadap usaha/tindakan yang dilakukan. Dalam hal ini subjek merasa yakin bahwa siswa slow learner bisa mengikuti pelajaran seperti yang lain. Sekalipun siswa slow learner memiliki kelemahan, namun subjek optimis bahwa siswa tersebut bisa. Subjek juga memiliki keyakinan mampu untuk memberikan perubahan pada siswa slow learner melalui usaha dan doa. Subjek selalu memiliki cara untuk menangani keterlambatan dari siswa slow learner yang ia hadapi, seperti inovasi dalam memberikan materi dengan kuis atau pesan berantai. Oleh karena itu, dapat dikatakan bahwa subjek mampu menghadapi kesulitan ketika menangani siswa slow learner.

b. Strength

Strength merupakan tingkat kepercayaan diri seseorang yang dapat diwujudkan dalam perilaku untuk meraih performa tertentu. Aspek ini mengacu pada besarnya kemantapan individu terhadap keyakinan/harapan yang dibuatnya.

Subjek memiliki keyakinan terhadap siswa slow learner yang tengah dibimbingnya, sehingga subjek melakukan berbagai cara untuk mengembangkan secara maksimal potensi yang dimiliki siswa tersebut. Subjek mencoba berbagai cara untuk membimbing siswa slow learner dalam meningkatkan kemampuan menulis dan membaca. Cara yang digunakan subjek antara lain dengan pemberian tugas, kuis, tebak-tebakan, pesan berantai, mendeskripsikan benda di depan kelas, dan membaca cerita di rumah dengan bantuan orangtua.

c. Generality

Generality berhubungan dengan cakupan bidang atau perilaku. Pengalaman dalam menyelesaikan tugas menimbulkan penguasaan terhadap bidang tugas tersebut dan meningkatkan keyakinan akan pengharapan dapat menyelesaikan tugas-tugas yang mirip atau yang lebih luas lagi. Subjek merasa bahwa dulu subjek pernah menangani siswa yang hampir sama dengan siswa slow learner yang tengah ia hadapi saat ini. Hanya saja, pada waktu itu subjek belum menyadari bahwa anak tersebut membutuhkan perhatian dan perlakuan khusus. Subjek tidak melakukan banyak hal terhadap siswa tersebut sebagaimana yang subjek lakukan saat ini. Subjek memiliki rasa penyesalan karena pada waktu itu tidak melakukan usaha yang maksimal untuk menangani kelambatan siswa tersebut. Oleh karena itu, dengan belajar dari 


\section{JPK (J urnal Pendidikan Khusus), 14 (1), 2018 - 5}

Farida Agustin Riyanda Putri, Fuadah Fakhruddiana

pengalaman tersebut, subjek saat ini berusaha secara maksimal agar siswa slow learner dapat tertangani dengan baik.

\section{Faktor-faktor yang mempengaruhi self-efficacy guru kelas}

Berdasarkan dari hasil wawancara yang telah dilakukan, faktor-faktor yang mempengaruhi subjek adalah sebagai berikut :

a. Enactive mastery experience (pengalaman keberhasilan terdahulu)

Subjek pernah menangani siswa slow learner sebelumnya, dan subjek tidak banyak melakukan banyak hal terhadap anak tersebut sehingga anak tersebut masuk ke dalam pondok orientasi. Hal inilah yang membuat subjek saat menangani siswa slow learner sekarang ini lebih banyak usaha agar siswa slow learner dapat masuk pondok yang bukan orientasi. Hal ini sesuai dengan faktor efficacy dari Bandura yakni enactive mastery experience (pengalaman keberhasilan terdahulu) bahwa orang yang mempunyai self-efficacy yang mumpuni akan belajar dari kegagalan tersebut dan berusaha lebih keras lagi untuk mencapai keberhasilan.

b. Vicarious experience (pengalaman orang lain)

Dalam menangani siswa slow learner, subjek juga melihat dari pengalaman orang lain. Subjek berkonsultasi dengan guru sebelumnya yang mengajar U (inisial untuk siswa), yakni significant person. Ketika mengajar U, guru sebelumnya mengalami kesulitan dalam mencari cara menghadapi keterlambatan U. Melalui hal tersebut, subjek mencoba mencari cara dengan membuat siswa senang, dan subjek mencari cara yang tepat untuk mengajar U.

Hal ini senada dengan pernyataan Bandura (1997) bahwa sumber informasi juga dipengaruhi oleh pengalaman orang lain dengan cara melihat apa yang telah dicapai orang lain. Orang yang memiliki efikasi diri yang tinggi, dapat belajar dari kegagalan orang lain dan berusaha lebih baik.

c. Verbal persuasion (persuasi verbal)

Subjek dan guru-guru lain saling bercerita tentang permasalahan dan saling memberi saran, juga saling menguatkan ketika menghadapi siswa berkebutuhan khusus. Menurut subjek, hal ini mempengaruhi proses mengajarnya ketika mendapat penguatan atau semangat dari guru lain. Hal ini disebabkan bahwa mengajar siswa berkebutuhan khusus itu tidak mudah.

Uraian tersebut sesuai dengan pernyataan Bandura (1997) bahwa efek sebuah nasihat bagi selfefficacy berkaitan erat dengan status dan otoritas pemberi nasehat. Selain itu, persuasi sosial berfungsi sebagai sarana lebih lanjut dalam memperkuat keyakinan seseorang bahwa dia memiliki kemampuan untuk mencapai apa yang mereka inginkan (Bandura, 1997).

Dalam temuan penelitian juga didapatkan faktor lain yang mempengaruhi Subjek I dalam membimbing siswa slow learner yaitu kondisi lingkungan dan fasilitas yang tersedia. Subjek I mengajar di sebuah yayasan dimana kondisi tempat dan fasilitas serba terbatas. Hal ini dimungkinkan memicu usaha subjek lebih keras dan tidak mudah putus asa dalam membimbing siswa slow learner. Kondisi lingkungan yang mempengaruhi perilaku subjek ini sesuai dengan teori ekologi Bronfenbrenner bahwa setting lingkungan sangat kuat mempengaruhi perkembangan individu (Santrock, 2010). Teori ekologi Bronfenbrenner terdiri dari lima sistem lingkungan yaitu mikrosistem, mesosistem, eksosistem, makrosistem dan kronosistem.

Dalam hal ini, subjek I dipengaruhi oleh kondisi mesosistem yang merupakan interaksi faktorfaktor dari mikrosistem (lingkungan sekolah). Sekolah dimana subjek I mengajar sangat mengutamakan perkembangan potensi masing-masing siswa, sehingga subjek I yang merupakan guru kelas dengan mengampu siswa slow learner, memiliki usaha yang lebih keras dalam proses mengajar. Interaksi dari kondisi fasilitas dan tuntutan pengembangan siswa inilah yang mampu mempengaruhi cara mengajar subjek yang begitu gigih dan mampu melihat celah-celah potensi siswa slow learner yang subjek hadapi.

\section{B. Subjek II}

\section{Dinamika Self-efficacy Guru Kelas dalam Membimbing Siswa Slow-Learner}

\section{a. Magnitude/level}

Magnitude/level merupakan suatu tingkat rasa keyakinan seseorang terhadap usaha/tindakan yang dilakukan. Subjek memiliki perasaan yakin ketika menghadapi dan membimbing siswa 


\section{J PK (J urnal Pendidikan Khusus), 14 (1), 2018 - 6}

Farida Agustin Riyanda Putri, Fuadah Fakhruddiana

slow learner, namun terkadang juga timbul rasa pesimis dalam dirinya ketika menghadapi siswa slow learner yang menangis. Selama ini, cara yang diterapkan subjek dalam menangani siswa slow learner hanya dengan menambah waktu pelajaran ketika jam istirahat ataupun jam pulang sekolah. Subjek belum melakukan cara lain dalam menangani kelambatan siswa slow learner tersebut secara efektif. Rasa pesimis dan terbatasnya cara yang dilakukan subjek dalam menghadapi dan membimbing siswa slow learner tersebut berkaitan dengan aspek level dari Bandura (1997) yaitu rasa keyakinan seseorang terhadap usaha/tindakan yang dilakukan berkaitan dengan tingkat kesulitan yang dihadapi.

b. Strength

Strength merupakan tingkat kepercayaan diri seseorang yang dapat diwujudkan dalam perilaku untuk meraih performa tertentu. Aspek ini mengacu pada besarnya kemantapan individu terhadap keyakinan/harapan yang dibuatnya. Subjek memiliki rasa pesimis ketika menghadapi siswa slow learner, hal ini membuat subjek tidak mampu melakukan banyak hal dalam membimbing siswa slow learner. Subjek hanya memberi pelajaran tambahan ketika jam istirahat atau jam pulang sekolah bagi siswa slow learner.

c. Generality

Generality berhubungan dengan cakupan bidang atau perilaku. Pengalaman dalam menyelesaikan tugas menimbulkan penguasaan terhadap bidang tugas tersebut dan meningkatkan keyakinan akan pengharapan dapat menyelesaikan tugas-tugas yang mirip atau yang lebih luas lagi. Subjek pernah mengalami kegagalan ketika membimbing siswa slow learner dengan tidak naiknya siswa tersebut, dan berdampak siswa tersebut menjadi 'minder'. Hal ini menjadi pembelajaran besar bagi subjek, sehingga ketika menangani siswa slow learner, subjek berusaha agar anak didiknya tertangani dengan baik, meskipun hal tersebut tidak serta merta mengurangi rasa pesimis yang subjek rasakan. Akan tetapi subjek tetap berusaha dengan selalu berkonsultasi dan tukar informasi bersama guru-guru lain yang di kelasnya terdapat siswa slow learner juga.

\section{Faktor-faktor yang mempengaruhi self-efficacy guru kelas}

Pada Subjek II , berdasarkan dari hasil wawancara yang telah dilakukan, faktor-faktor yang mempengaruhi Subjek II adalah sebagai berikut:

a. Enactive mastery experience (pengalaman keberhasilan terdahulu)

Subjek belajar dari kegagalan yang terdahulu ketika mengajar siswa yang lambat, sekalipun cara yang digunakan sama, namun dari pengalaman tersebut subjek lebih berusaha kembali dalam mengajar siswa slow learner.

b. Vicarious experience (pengalaman orang lain)

Subjek saling bertukar informasi dengan guru lain dalam mengajar siswa yang lambat. Namun subjek tidak selalu menerapkan cara yang dilakukan guru lain. Hal ini senada dengan pernyataan Bandura (1997) bahwa sumber informasi juga dipengaruhi oleh pengalaman orang lain dengan cara melihat apa yang telah dicapai orang lain.

c. Verbal persuasion (persuasi verbal)

Subjek dan guru lain saling memberi saran, hal ini yang membuatnya tidak merasa sendiri ketika menghadapi siswa slow learner. Hal tersebut sesuai dengan pernyataan Bandura (1997) bahwa efek sebuah nasihat bagi self-efficacy berkaitan erat dengan status dan otoritas pemberi nasehat. Selain itu, persuasi sosial berfungsi sebagai sarana lebih lanjut dalam memperkuat keyakinan seseorang bahwa dia memiliki kemampuan untuk mencapai apa yang mereka inginkan (Bandura, 1997).

d. Physiological and affective states (keadaan fisiologis dan afeksi)

Dalam menghadapi siswa slow learner, subjek terkadang merasa lelah ketika siswa tersebut sulit diberi instruksi. Ditambah dengan tanggungjawab yang diberikan kepala sekolah untuk membuat rancangan pembelajaran bagi siswa, subjek merasakan ada beban tersendiri. Hal ini diperkuat oleh pernyataan dari significant person bahwa subjek sedikit suka mengeluh.

Keyakinan yang dimiliki oleh Subjek II menentukan seberapa besar kesempatan lingkungan dan rintangan yang berhubungan dengan siswanya, diterima olehnya sehingga mempengaruhi usaha Subjek II dalam memberikan pembelajaran bagi siswanya. Usaha yang dilakukan Subjek II hanya menambah waktu pelajaran ketika jam istirahat ataupun jam pulang sekolah. Subjek belum melakukan 


\section{J PK (J urnal Pendidikan Khusus), 14 (1), 2018 - 7}

Farida Agustin Riyanda Putri, Fuadah Fakhruddiana

cara lain dalam menangani kelambatan siswa slow learner tersebut secara efektif. Selain itu juga ada unsur kelelahan pada diri Subjek II dalam menghadapi siswanya sehingga sering mengeluh dan menyebabkan usahanya juga kurang maksimal.

Dari gambaran kedua subjek, dapat diperoleh kesimpulan bahwa self-efficacy akan memberikan kekuatan bagi guru dalam menghadapi siswa slow learner. Hal ini sebagaimana yang dikemukakan oleh Schunk dan Meece (2006) bahwa self-efficacy mempengaruhi tujuan dan perilaku seseorang (Skaalvik \& Skaalvik, 2009). Keyakinan diri akan menentukan seberapa besar kesempatan lingkungan dan rintangan akan diterima (Bandura, 2006a) dan mempengaruhi pilihan aktivitas, seberapa besar upaya akan dilakukan dalam aktivitas tersebut, dan seberapa lama seseorang akan tekun menghadapi rintangan (Skaalvik \& Skaalvik, 2009). Sesuai sekali dengan gambaran yang diperoleh pada Subjek I bahwa ia berusaha mengupayakan mencoba berbagai cara untuk membimbing siswa slow learner dalam meningkatkan kemampuan menulis dan membaca. Cara yang digunakan subjek antara lain dengan pemberian tugas, kuis, tebak-tebakan, pesan berantai, mendeskripsikan benda di depan kelas, dan membaca cerita di rumah dengan bantuan orangtua. Sementara Subjek II karena timbul rasa pesimis, maka usaha yang dilakukan pun menjadi terbatas dalam menghadapi dan membimbing siswanya. Menurut Tschannen-Moran \& Hoy (2007), penting untuk dicatat bahwa self-efficacy merupakan konstruksi motivasi yang berdasarkan pada persepsi diri terhadap kompetensinya daripada level kemampuannya. Hal ini tentu akan memberi pengaruh bagi kekuatannya untuk melakukan upaya yang terbaik bagi siswanya, meskipun bisa jadi bila ditinjau dari level kemampuannya dapat dikatakan kurang sebagai guru pendamping siswa berkebutuhan khusus.

Faktor lain yang ditemukan dalam penelitian ini adalah kondisi lingkungan mengajar subjek. Berbeda dengan Subjek I yang kondisi lingkungan dengan fasilitas terbatas, Subjek II mengajar di sekolah negeri dengan fasilitas yang cukup, serta orientasi sekolah yang kurang menuntut adanya fokus individual siswa. Hal ini dimungkinkan membuat Subjek II kurang berusaha keras untuk mengembangkan potensi siswa inklusi termasuk siswa slow learner. Dalam hal ini, Subjek II juga dipengaruhi oleh kondisi mesosistem yang merupakan interaksi faktor-faktor dari mikrosistem (lingkungan sekolah). Banyaknya siswa, serta sistem sekolah yang kurang menuntut perngembangan potensi siswa, dimungkinkan mempengaruhi kinerja subjek dalam mengajar. Hal ini ditambah dengan adanya guru pendamping khusus yang didatangkan setiap 2 kali dalam seminggu untuk mendampingi siswa berkebutuhan khusus, membuat guru kurang memacu usahanya dalam mengajar dikarenakan mengandalkan guru pendamping tersebut dalam membimbing siswa slow learner.

\section{SIMPULAN}

\section{Subjek I}

a. Self-efficacy guru kelas dalam membimbing siswa slow learner

Subjek I memenuhi ketiga aspek self-efficacy dari teori Bandura (1997) dalam membimbing siswa slow learner. Selain itu, tindakan yang dilakukan subjek dalam menghadapi siswa slow learner sesuai dengan pernyataan Bandura bahwa guru yang memiliki self-efficacy tinggi cenderung bertindak pada keyakinan bahwa siswa yang sulit diajar, dengan upaya ekstra dan teknik yang tepat, mereka dapat tertangani melalui pembelajaran yang efektif. Subjek menanamkan keyakinan bahwa siswa slow learner memiliki potensi yang mampu berkembang. Subjek mampu menghadapi kesulitan ketika cara yang dilakukan untuk menangani siswa slow learner tidak membuahkan hasil. Subjek memiliki banyak ide dan cara untuk mengurangi kelambatan yang dialami siswa slow learner.

b. Faktor-faktor yang mempengaruhi self-efficacy guru kelas

Self-efficacy subjek dipengaruhi oleh empat faktor yakni pengalaman keberhasilan terdahulu, pengalaman orang lain, persuasi verbal dan kondisi fisik dan afeksi. Hal tersebut berupa pengalaman kegagalan subjek yang terdahulu dalam menangani siswa slow learner dengan tidak maksimal, kemudian pengalaman dari guru lain yang pernah menangani siswa slow learner yang saat ini subjek tangani, saran dan penguatan dari orang lain, serta subjek yang tidak pernah mengeluh maupun berputus asa dalam membimbing siswa slow learner. Faktor lain juga ditemukan yaitu pengaruh kondisi lingkungan subjek mengajar dimana tempat dan fasilitas serba terbatas. 


\section{J PK (J urnal Pendidikan Khusus), 14 (1), 2018 - 8}

Farida Agustin Riyanda Putri, Fuadah Fakhruddiana

\section{Subjek II}

a. Self-efficacy guru kelas dalam membimbing siswa slow learner

Subjek II juga memenuhi ketiga aspek self-efficacy dari teori Bandura (1997) dalam membimbing siswa slow learner. Akan tetapi perwujudan tindakan subjek kurang mampu dalam menghadapi kesulitan ketika menghadapi siswa slow learner di dalam kelas, bahkan terkadang muncul rasa pesimis. Subjek kurang memiliki inovasi dalam mengajar, sehingga cara yang digunakan untuk mengurangi kelambanan siswa hanya mengandalkan penambahan jam pelajaran saja.

b. Faktor-faktor yang mempengaruhi self-efficacy guru kelas

Self-efficacy subjek dipengaruhi oleh empat faktor yakni pengalaman keberhasilan terdahulu, pengalaman orang lain, persuasi verbal dan kondisi fisik dan afeksi. Hal tersebut berupa kegagalan yang pernah dialami subjek menjadikan subjek berusaha lagi dalam membimbing siswa slow learner, kemudian informasi yang didapat subjek dari guru lain, pemberian saran dan semangat dari sesama guru yang menghadapi siswa slow learner, serta kondisi subjek yang sedikit suka mengeluh dan merasa memiliki beban. Hal inilah yang menunjukkan bahwa subjek memiliki self-efficacy yang cenderung kurang dibandingkan dengan subjek I.

\section{DAFTAR PUSTAKA}

Balai Pengembangan Pendidikan Khusus Dinas Pendidikan Provinsi Jawa Tengah. (2014). Data statistik siswa inklusi. Diunduh dari http://www.bpdiksus.org/v2/index.php?page=sisink

Bandura, A. (1997). Self-efficacy: The exercise of control. New York: Freeman and Company.

Brouwers, A. \& Tomic, W. (1999). A longitudinal study of teacher burnout and perceived selfefficacy in classroom management. Teaching and Teacher Education 16 (2000) 239 - 253

Poerwandari, K. (2009). Pendekatan kualitatif untuk penelitian perilaku manusia. Jakarta: Lembaga Pengembangan Sarana Pengukuran dan Pendidikan Psikologi (LPSP3).

Rudiyati, S., Pujianingsih, \& Ambarwati, U. (2010). Penanganan anak berkesulitan belajar berbasis akomodasi pembelajaran. Jurnal Kependidikan Vol. 40. No. 2. Hal 182-200.

Santrock, J.W. (2010). Psikologi pendidikan. Edisi kedua. Jakarta: Kencana.

Skaalvik, E.M. \& Skaalvik, S. (2007). Dimensions of Teacher Self-Efficacy and Relations With Strain Factors, Perceived Collective Teacher Efficacy, and Teacher Burnout. Journal of Educational Psychology. Vol. 99, No. 3, 611-625.

Skaalvik, E.M. \& Skaalvik, S. (2009). Teacher self-efficacy and teacher burnout: A study of relations. Teaching and Teacher Education 26 (2010) 1059 - 1069.

Suyanto \& Jihad, A. (2013). Menjadi guru profesional. Jakarta: Esensi Erlangga Grup.

Tschannen-Moran, M. \& Hoy, A.W. (2007). Antecedents of teacher self-efficacy: The differential antecedents of self-efficacy beliefs of novice and experienced teachers. Teaching and Teacher Education. Vol. 23. Issue 6. Pages 944-956.

Widayanti, Costrie G., Rusmawati, D., \& Siswati. (2012). Profil inteligensi pada siswa dengan kesulitan belajar di SD Negeri Gisikdrono Semarang. Jurnal Psikologi UNDIP Vol. 11. No.1. 